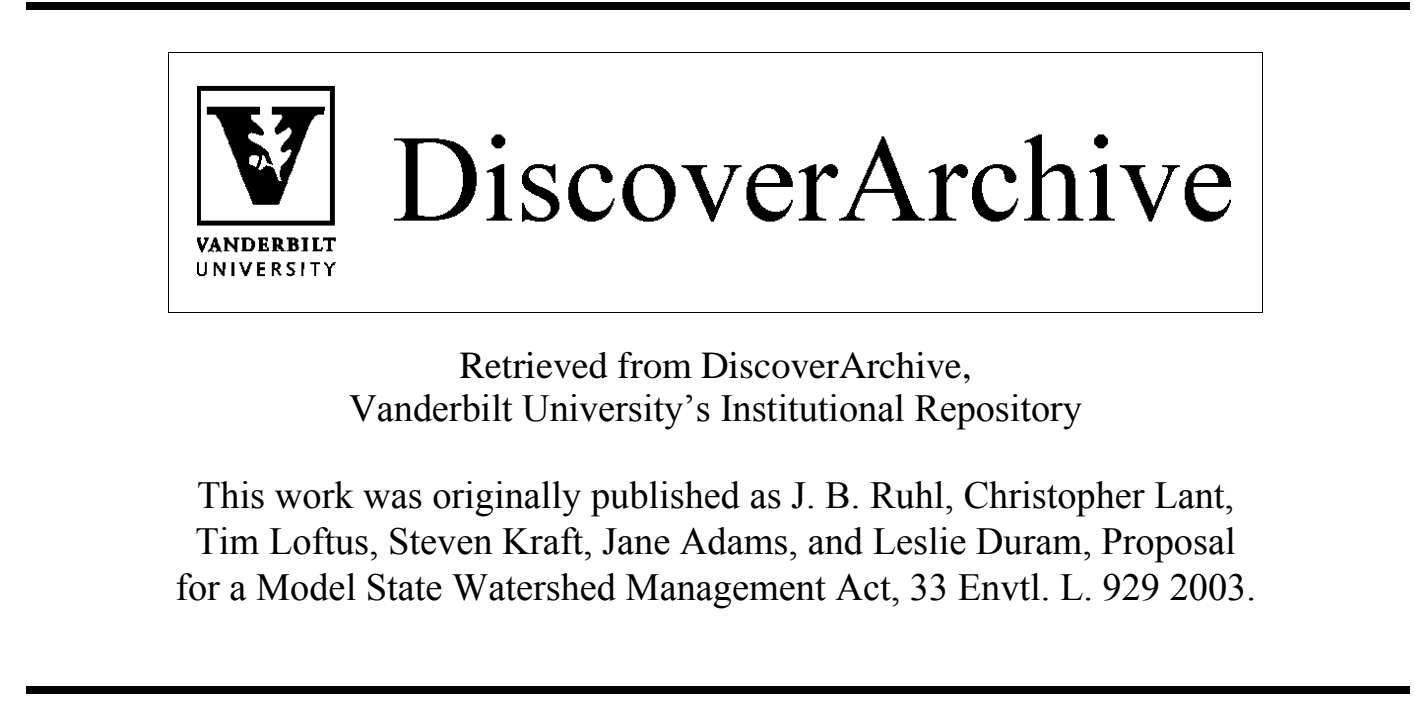




\title{
PROPOSAL FOR A MODEL STATE WATERSHED MANAGEMENT ACT
}

\author{
BY \\ J.B. Ruhl, ${ }^{1}$ Christopher Lant, ${ }^{2}$ Tim Loftus,${ }^{3}$ Steven Kraft,${ }^{4}$ Jane Adams,${ }^{5}$ \\ AND LESLIE DURAM ${ }^{6}$
}

During the Montana Constitutional Convention of 1889, John Wesley Powell, envisioning a landscape of "watershed commonwealths," proposed that Montana adopt watersheds as the boundaries of its counties. The idea did not catch on. Over time, the power of local governments to regulate land use has grown immensely, but the misfit between their political boundaries and environmental policy "problemsheds" has persisted. As the understanding of ecosystem dynamics improves, however, natural resources management policy is gravitating, once again, to the watershed as an appropriate unit of governance. Many federal and state natural resource management initiatives have come online in the past five years using watersheds as their primary focus. Yet these new programs lack coherence and invest inadequate authority in watershed-based units of government. This Article proposes the framework for a model state watershed management law. It concludes that the federal government is illequipped to take on the role of comprehensive watershed management czar as it has for pollution control and other environmental programs. Yet local governments, even if organized around watershed boundaries, are unlikely to provide the platform for effective policy implementation. Rather, this Article proposes a multi-tiered governance system linking state, regional, and local units of government through careful distribution of planning responsibilities and policy implementation authorities. Although for many states this framework would introduce a new "layer" of governance, its superior

\footnotetext{
• (C) J.B. Ruhl, Christopher Lant, Tim Loftus, Steven Kraft, Jane Adams, and Leslie Duram, 2003.

1 Matthews \& Hawkins Professor of Property, Florida State University College of Law, Tallahassee, Florida. Please direct comments or questions on this article to jruhl@law.fsu.edu.

2 Department Chair and Professor, Geography Department of Southern Illinois UniversityCarbondale, Carbondale, Illinois.

3 Director, Heidelberg College Water Quality Laboratory, Tiffin, Ohio.

4 Department Chair and Professor, Agribusiness Economics Department of Southern Illinois University-Carbondale.

5 Associate Professor, Anthropology Department of Southern Illinois UniversityCarbondale.

${ }^{6}$ Associate Professor, Geography Department of Southern Illinois University-Carbondale.
} 
correspondence to the inescapable realities of ecosystem dynamics makes it worthy of serious consideration.

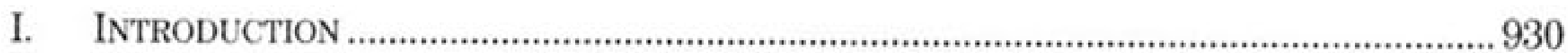

II. DESIGN PaRAMETERS For WATERShEd MANAGEMENT LAW............................................. 933

III. The NeEd For a State-Level Watershed Management Initiative .........................995

IV. Key Features of the Model State Watershed Management Act.........................939

V. The Proposed Institutional Framework ................................................................ 942

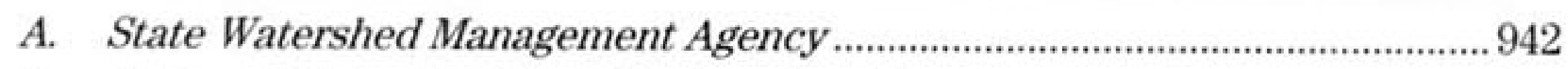

B. Regional Watershed Coordination Agencies................................................... 943

C. Local Watershed Management Councils .......................................................9945

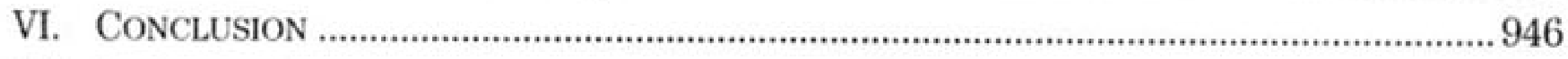

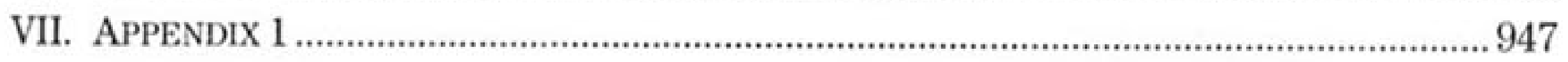

\section{INTRODUCTION}

The progress of watershed management stands at a fork in the political road. It is widely agreed that implementing watershed management, to the extent it grows in importance as an organizing policy foundation, is complicated by the mismatch between watershed boundaries and conventional political boundaries. ${ }^{7}$ Finding the right "fit" between the two realms presents difficult choices when constructing political institutions. On the one hand, as we increasingly understand that the "problemshed" of most water quality and water quantity issues corresponds more closely to geographically delineated watersheds, ${ }^{8}$ proposals for new watershed-based political structures have grown more focused..$^{9}$ On the other hand, many local government authorities have extended beyond their traditional role as land-use regulators into environmental protection and resource conservation, giving many watershed management advocates hope that existing local political structures may play a central role in shaping and

7 See A. Dan Tarlock, The Potential Role of Local Governments in Watershed Management, 32 Envtl. L. Rep. (Envtl. L. Inst.) 11,273, 11,273-74 (2002) (addressing the evolving role of local government in watershed conservation). See also Robert W. Adler, Addressing Barriers to Watershed Protection, 25 ENVTL. L. 973, 973-1106 (1995) (commenting on local watershed management in addition to providing a comprehensive overview of watershed management law and policy in general, which this Article does not purport to provide).

$8 \mathrm{~A}$ watershed is "a geographic area of land, water, and biota within the confines of a drainage divide. The total area above a given point of a water body that contributes flow to that point." Department of Agriculture et al., Unified Federal Policy for a Watershed Approach to Federal Land and Resource Management, 65 Fed. Reg. 62,566, 62,572 (Oct. 8, 2000).

9 See, e.g., Douglas S. Kenney, Historical and Sociopolitical Context of the Western Watersheds Movement, in HuMAN DimEnsions of WATERSHED MANAGEMENT, AMERICAN WATER Resources Association, Monograph Series No. 20, 493, 493-503 (Christopher L. Lant ed., 1999); J. B. Ruhl, The (Political) Science of Watershed Management in the Ecosystem Age, $35 \mathrm{~J}$. AM. WATER RESOURCES ASS'N 519 (1998). 
implementing watershed management policy. ${ }^{10}$ Watershed management, it seems, is as much a political science as it is a physical science. ${ }^{11}$

The connection between the physical and political dynamics of watersheds has become increasingly apparent. Decades ago researchers demonstrated that land-use patterns within watersheds have a dominant influence on the hydrologic regime, water quality, and physical habitat of streams and rivers, and on the ecological interactions that take place in the aquatic ecosystem. ${ }^{12}$ More recently, researchers have targeted restoration of the physical integrity of rivers while using a watershed framework across a wide range of geographic environments, focusing on facilitating the dynamics of rivers as the key to reversing the rapid decline of aquatic ecosystems in the United States. ${ }^{13}$ In short, watershed-based problemsincluding river fragmentation from the construction of dams, the loss of riverine wetlands, and the separation of river channels from floodplains through levees-demand watershed-based solutions.

Accordingly, the need for watershed-based land-use and resource management has gradually been integrated into concrete policy objectives. The idea itself is not new by any means, ${ }^{14}$ and numerous historical antecedents to watershed-based policy frameworks exist, ${ }^{15}$ but none are as comprehensive as what we are witnessing today. For example, the most recent Army Corps of Engineers Strategic Plan identifies environmental repair on a watershed basis as one of its primary goals. ${ }^{16}$ The United States Environmental Protection Agency (EPA) has recently taken even broader steps than the Army Corps of Engineers by committing itself to pursuing "multi-stakeholder efforts within hydrologically defined boundaries to protect and restore our aquatic resources and ecosystems." ${ }^{17}$ This

10 See Tarlock, supra note 7, at 11,274-83.

11 The importance of this choice between political structures has been illustrated in concrete settings. See Alice L. Jones \& Steven I. Gordon, From Plan to Practice: Implementing Watershed-Based Strategies into Local, State, and Federal Policy, 19 ENVTL. Toxicology AND CHEMISTRY 1136, 1138-41 (2000) (comparing the "transboundary approach," in which hydrologically designed authorities implement policy, to the "simultaneous independent approach," in which existing local governments attempt to coordinate policy, as the two approaches that might be implemented in the Big Darby Creek watershed in Ohio, which encompasses 7 counties, 11 cities, and 26 townships).

12 See James R. Karr \& Daniel R. Dudley, Ecological Perspective on Water Quality Goals, 5 EnvTL. MgmT. 55, 55-68 (1981) (examining nonpoint pollution abatement programs in the context of the Black Creek Project in Indiana).

13 William L. Graf, Damage Control: Restoring the Physical Integrity of America's Rivers, 91 ANNAIS ASs'N AM. GEOGRAPHERs 1, 1-27 (2001).

14 John Wesley Powell, envisioning "watershed commonwealths," proposed that Montana adopt watersheds as the boundaries of counties during the Montana Constitutional Convention of 1889. Donald Snow, The Persistence of Powell: The Idea of Watersheds and Participatory Democracy, 23 J. LAND Resources \& ENVTL. L. 31, 37 (2003).

15 See William E. Taylor \& Mark Gerath, The Watershed Protection Approach: Is the Promise About to Be Realized?, 11 NAT. RESOURCES \& ENV'T 16 (1996) (explaining some of the early approaches and illustrating the comprehensive approaches currently emerging).

16 DEP'T OF THE ARMY, CORPS OF ENGINEERS, Civil Works Program STrategic Plan FY 2003FY 2008, at 51 (2002) [hereinafter CORPS STRATEGIC PLAN], available at http://www.iwr.usace.army.mil/iwr/strategicplan.htm.

17 Memorandum from G. Tracy Mehan, III, Assistant Administrator, EPA to Office Directors 
"watershed or 'place-based' approach" is, according to the initiative, "one of the most important environmental guiding principles" for the current administration. ${ }^{18}$ At least twenty states have also adopted some form of statewide watershed management policy for purposes of managing at least some aspects of water quality protection. ${ }^{19}$ It is not surprising, therefore, that the National Research Council recently concluded that "[m]any factors are converging to cause citizens, scientists, resource managers, and government decisionmakers to look increasingly to watershed management as an approach for addressing a wide range of water-related problems." 20

Nevertheless, while the need for a watershed-based approach has become a basic tenet of policy, it is not nearly as clear how to match political structures to the problem so defined. The EPA has established the Watershed Management Council, comprised of representatives from the agency's headquarters and regional offices, to integrate the watershed into the agency's planning and policy apparatus. But the initiative contemplates no explicit federal, state, or local governance structure for watershed management. Indeed, EPA observes that "there can be many variations in the specific approaches states use to implement programs on a watershed basis" and thus declines to suggest a particular watershed management model, leaving it instead for the states to implement "the approaches they find work best for them." ${ }^{21}$ Yet, while we applaud EPA's movement toward the watershed approach, we are concerned with the agency's apparent indifference to the absence of a model for the development of state watershed management law.

Being far from indifferent about the matter, in this Article we take the step of proposing a framework for a model state watershed management law. Our model law establishes a three-tiered governance structure within which the authority, expertise, and accountability for watershed-based decision making are carefully distributed so as to balance the physical and political realities of watersheds and watershed management. In Part II of this Article, we lay out what we believe are the critical design parameters for any legal framework intended to implement the watershed management approach across large geographic scales. In Part III, we explain our reasons

and Regional Water Division Directors, EPA (Dec. 3, 2002), [33 Current Developments] Env't Rep. (BNA) 2727 (Dec. 3, 2002) [hereinafter Mehan Memo], available at

http://www.epa.gov/owow/watershed/memo.html.

18 Id. EPA is taking steps to ground this policy in practical applications, such as the agency's ongoing initiative to implement a watershed-based water pollutant permitting program under the Clean Water Act. See Notice of Availability: Draft Watershed-Based National Pollutant Discharge Elimination System (NPDES) Permitting Implementation Guidance, 68 Fed. Reg. 51,011 (Aug. 25, 2003) (making a draft watershed permitting implementation guidance available for public comment).

19 EPA recently described in considerable detail the diversity of watershed management approaches of the twenty states that had adopted some form of statewide law or policy. See generally USEPA, OFFICE of WATER, A REVIEW of STATEWIDE WATERShed Management APPROACHES (2002).

20 Nat'l ACAdEmy of Sciences, Nat'l Research CouncIl, New Strategies for America's WATERSHEDS 1 (1999) [hereinafter NEw STRATEGIES].

21 Mehan Memo, supra note 17. 
for proposing a model state enabling law rather than either a comprehensive federal regulatory law or a model local ordinance. In Part IV, we outline the basic theoretical underpinnings of the approach we have taken in our model state law. Part V outlines the key features of the model law, providing annotated explanations of and justifications for its critical components.

\section{DESIGN PARAMETERS FOR WATERSHED MANAGEMENT LAW}

The objective of treating watershed-based problems through watershedbased political institutions raises many foundational issues. In particular, three themes emerge as critical to the discussion of watershed-based political structures. First, watersheds, even where they can be clearly delineated, come in many sizes, and their different scales often are "nested" in hierarchies of relatedness. ${ }^{22}$ In a large riverine system, for example, the cumulative impacts of land-use actions taken in countless small tributary watersheds may have profound impacts in the river mainstem and estuary. Seasonal hypoxia in the northern Gulf of Mexico offers a striking example of such cumulative impacts. ${ }^{23}$ Hence, one core issue of watershed management is the scale at which to design watershed-based political institutions and how the related nature of different physical scales can be reflected in political boundaries.

Second, even using watershed-based political boundaries, water quality and water quantity issues cannot always be described and addressed though intrashed features, or even through exclusively water-based features. Air pollution from sources within or even beyond a watershed's boundary may profoundly affect its water quality, ${ }^{24}$ and water supply demands from local or distant populations can impair water availability in a watershed..$^{25}$ Yet as the political unit's scope of authority increases both in geographic extent and in subject matter, the institution's legitimacy to effect change at local levels may be more difficult to establish and maintain. ${ }^{26}$ Accordingly, once

22 See J. Omernik \& R. Bailey, Distinguishing Between Watersheds and Ecosystems, 33 J. AM. WATER RESOURCES ASs'N 935, 935-50 (1997) (clarifying the difference between watershed framework and eco-region framework for the purpose of enabling agencies to use the frameworks in conjunction).

23 Mississippi RIVER/Gulf of Mexico Watershed Nutrient Task Force, ACtion Plan for REducing, Mitigating, AND CONTROLling HyPOXIA IN THE NORTHERn GULF OF MEXICO 5 (2001).

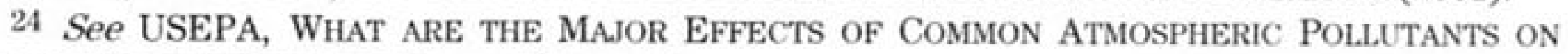
WATER QUALITY, ECOSYSTEMS, AND HUMAN HEALTH,

http:/www.epa.gov/owow/oceans/airdep/air3.html (last visited Nov. 16, 2003) (addressing the effects of nitrogen compounds, metals, mercury, pesticides, and combustion emissions on water, ecosystems, and humans).

25 Marc Reisner, Cadillac Desert: The American WeSt and ITS DisapPEARING Water 12526 (1993).

26 S. Kraft et al., Ecological Restoration in Multiple-Ownership Watersheds: The Case of the Cache River in Illinois-Social and Economic Issues, in GOVERNOR'S CONFERENCE ON THE Management of THE Illinois River System, Eighth BIENNIAL CONFEREnCE: THe Illinois RIVER: PARTNERShIPS FOR Progress, Restoration, AND PREservation 161 (2001) [hereinafter Ecological Restoration]. 
their boundaries are delineated, what is the appropriate geographic and substantive scope of authority for watershed-based political units?

Finally, as watershed-based political institutions would serve limited purposes, conventional political entities such as cities and counties would surely continue to exist for many other purposes. Presumably, however, some of the authority previously enjoyed by various existing political entities would be transferred to or shared by the new watershed-based institutional structure. Thus, watershed management policy must confront the question of how watershed-based political institutions will be "overlain" on the existing political framework such that these divisions of authority are clear and respected.

In his sweeping exploration of the state of watershed management initiatives, Professor Robert Adler anticipates these three themes in his discussion of five basic "design issues" for watershed management institutions-the definition of scale, boundary, control, mission, and consistency. ${ }^{27}$ The three themes also arise in later studies examining the issue of watershed management in general, ${ }^{28}$ as well as in studies of specific watershed projects and settings such as the Chesapeake Bay, ${ }^{29}$ watershed groups in California, ${ }^{30}$ and in our own interdisciplinary work examining the historical, political, and economic aspects of watershed planning in southern Illinois. ${ }^{31}$ Our study of the issue has led us to conclude that several overarching institutional design goals should shape the approach taken to answering these three foundational questions. The institutional design goals are as follows:

1) The institutional structure for watershed management must enjoy the type of power and authority generally associated with centralized administrative governments, such as the federal or state governments, but must also be capable of establishing democratically based legitimacy at regional and local levels where many regulatory actions are implemented. This requires going beyond federal or state laws enabling local districts to take action. Rather, much like watersheds themselves, a nested hierarchy of interrelated federal, state, and local governmental authorities will be necessary.

2) The institutional structure must have the authority and the responsibility to manage watershed issues "holistically" on a system level. This requires, at a minimum, some form and level of authority over surface and ground water, over water quality and water quantity, and over key physical and biological effects on aquatic ecosystems such as flood control,

27 Adler, supra note 7, at 1088.

28 See New Strategres, supra note 20, at 9-10 (arguing for a flexible application of watershed principles).

29 See Joe Cannon, Choices and Institutions in Watershed Management, 25 WM. \& MARY ENVTL. L. \& POL'Y REV. 379, 381-91 (2000) (applying the themes to institutional analysis in the Chesapeake Bay region).

30 See John T. Woolley et al., The California Watersheds Movement: Science and the Politics of Place, 42 NAT. Resources J. 133, 134-35 (2002) (concluding that areas without watershedbased organizations have slightly poorer water quality than areas with such organizations).

31 See Ecological Restoration, supra note 26, at 161. 
soil conservation, wetlands conservation, fisheries, recreation, stream entrenchment, dams, reservoirs, pollutant sources, and land uses with significant watershed impacts.

3) The institutional structure must rely on more than voluntary governance and voluntary compliance with specified standards and goals. In particular, where implementation relies on local units of governance, accountability must be lodged at the local level. The full range of financing mechanisms should be made available (e.g., taxes, fees, surcharges, bonds) and the full range of compliance instruments should be capable of being used effectively as appropriate (e.g., regulatory and market-based incentives, reporting and information requirements, planning requirements, voluntary actions).

4) The institutional structure must have the capacity-the budget, staff, and expertise-to carry out complex scientific, economic, and social analysis functions, as well as the responsibility to make policy and regulatory decisions through public, transparent procedures based on the record of the best available evidence it generates through its capacities.

5) The institutional structure should be generalizable across watershed types, scales, and political units, and the information-gathering capacity and protocols should be standardized so as to allow sharing of information vertically (e.g., within a state from local to higher levels) and horizontally (e.g., between local districts and between states).

Our proposed framework for a model state watershed management law is intended to make these five design goals operational. A critical premise of our approach, to which we turn in the next section, is that doing this requires a comprehensive and coordinated effort led by the states-that is, not the federal or local governments-and implemented at several levels of governance within each state.

\section{The NeEd For a State-Level Watershed Management Initiative}

Many of our nation's environmental policy concerns have been addressed through comprehensive federal regulatory laws, such as the Clean Water $\mathrm{Act}^{32}$ and Clean Air Act, ${ }^{33}$ that rely heavily on nationally prescribed standards and centralized regulatory and policy decision making. ${ }^{34}$ While states often play a large role in administration and enforcement of these federal statutes, federal authority is paramount and local autonomy is minimal. ${ }^{35}$ These laws have unquestionably led to tremendous gains in

32 Federal Water Pollution Control Act, 33 U.S.C. $\$ \S 1251-1387$ (2000).

3342 U.S.C. $\$ \$ 7401-7671 q$ (2000).

34 See EPA, Water Quality Trading Policy; Issuance of Final Policy, 68 Fed. Reg. 1608, 1609 (Jan. 13, 2003) [hereinafter Water Quality Trading Policy] (describing the nationally applied, technology-based permitting standards approach traditionally used under the Clean Water Act). See generally James SALZMAN \& BARTON THOMPSON, ENVIRONMENTAL LAW AND POLICY 77-122 (overview of Clean Air Act); id. at 123-46 (overview of Clean Water Act); ROBERT W. ADLER ET AL., The Clean Water Act: 20 Years LAter 137-70 (1993) (history of Clean Water Act implementation).

35 See Water Quality Trading Policy, supra note 34, at 1609 (The Clean Water Act 
environmental quality, ${ }^{36}$ but their model is seldom offered as the solution to issues most frequently cited as the challenges of the future for environmental policy, such as diffuse nonpoint source water pollution from urban and agricultural land uses. ${ }^{37}$

Indeed, several factors strongly suggest that a comprehensive federal regulatory law is not the most effective or efficient vehicle for carrying out the policy challenges our design parameters present. First, watersheds vary across many dimensions throughout the national landscape and respond primarily to local land-use and water-use actions. It is difficult to envision a set of nationally uniform standards, such as the approach taken in the Clean Water Act and Clean Air Act, ${ }^{38}$ for managing them that could be efficiently implemented. Second, support for centralized regulation of natural resources, in general, has eroded the desire for more state and local control of key land-use decisions. The Strategic Plan of the Army Corps of Engineers, for example, emphasizes stronger local partnerships with "a shift from regulator/advisor to facilitator/partner" relationships with local governments and stakeholder groups. ${ }^{39}$ EPA's recent statement of commitment to the watershed approach adopts the same theme. ${ }^{40} \mathrm{~A}$ federal regulatory statute governing watershed management would thus risk failure to establish legitimacy at local levels.

On the other hand, we would not suggest that the federal government remove itself entirely from the objective of influencing state and local watershed management initiatives. As the Coastal Zone Management Act (CZMA $)^{41}$ illustrates, federal law can be useful as a motivator for state action without intruding on basic design choices. ${ }^{42}$ There are undoubtedly some

implemented a national regulatory program but also preserved "the primary responsibilities and rights of the States to prevent, reduce and eliminate pollution."). Under this system "states were assigned the role of federal implementation agents and allowed to run federal and parallel state programs as long as they complied with federal floors. Local governments were effectively either classified as polluters or left to deal with unambiguously local nuisances such as noise." Tarlock, supra note 7 , at 11,276.

36 See Water Quality Trading Policy, supra note 34, at 1609 ("The application of technology and water quality based requirements ... has achieved and remains critical to success in controlling point source pollution and restoring the nation's waters".).

37 See J.B. Ruhl, Farms, Their Environmental Harms, and Environmental Law, 27 EcologY L.Q. 263, 265 (2000) (examining the failure of conventional environmental law to address agricultural runoff and proposing more flexible approaches). This experience has led the EPA to advocate new approaches to nonpoint source pollution, including watershed-based pollutant trading, as superior to conventional command-and-control regulation. See Water Quality * Trading Policy, supra note 34, at 1609 (New approaches such as pollutant trading "provide greater flexibility and have potential to achieve water quality and environmental benefits greater than would otherwise be achieved under more traditional regulatory approaches.").

38 See SAlzMAN \& THOMPSON, supra note 34, at 77-89 (Clean Air Act standards); $i d$. at 129-38 (Clean Water Act standards).

39 CorPs Strategic Plan, supra note 16, at 38.

40 See Mehan Memo, supra note 17 (describing "local capacity building" as one of the central objectives of EPA's watershed initiative).

4116 U.S.C. $\$ \$ 1451-1465$ (2000).

42 The CZMA establishes national goals for coastal resource protection, but establishes no federal regulatory program to implement those goals. Rather, it relies heavily on states to implement the national policy through state-designed land management frameworks, in return 
national objectives for watershed management (e.g., to address nonpoint source pollution, to conserve endangered species), which, while not lending themselves to nationally uniform standards, may nonetheless justify federal support for states that satisfy the national concerns as they become increasingly and more formally involved in watershed management within their boundaries. Like the CZMA, a federal watershed initiative could express broad national goals and standards and establish a mechanism for states to submit their respective watershed management programs for federal approval, offering in return federal financial support for design and implementation as well as the commitment that federal agencies will not carry out, fund, or authorize actions inconsistent with the state plan. At the very least, the federal government can and ought to maintain an important role as a source of scientific data and research that has broad usefulness to state-based watershed institutions and as an environmental engineering contractor, such as through the Army Corps of Engineers. At the most, however, the federal government might consider ways to influence state policy through a statute, like the CZMA, that provides cooperative support for state action. Full-blown command-and-control style federal regulation imposing watershed management is not advised.

For different-but equally compelling-reasons, effective watershed management regimes cannot rely exclusively on the initiative of local governance, particularly if channeled through conventional local political entities. Even putting aside the lack of match between conventional local political boundaries and watersheds, local governments face several constraints to effective watershed management. First, while most state political systems allow considerable local authority-certainly enough to establish watershed ordinances-management of transboundary effects often lies outside their authority or is able to be undertaken only through burdensome interlocal coordination procedures. ${ }^{43}$ Second, many watershed management issues will present difficult political choices with potentially significant economic consequences, and local governments, particularly those constituted by popular election, may be reluctant to make economic sacrifices not being made by others. ${ }^{44}$ Finally, even with most local governments committed to watershed management, it is doubtful that all could afford the intensive scientific, social, and economic data gathering and analysis necessary to carry it out effectively. Small rural counties, for example, are already hard-pressed to support water quality requirements of

\footnotetext{
for which a cooperating state receives federal financial assistance and a commitment by federal agencies not to interfere with the state's coastal protection plan. In this sense the CZMA is unusual among federal environmental laws. See JOHN NAGLE \& J.B. RUHL, THE LAW OF BIODIVERSITY AND ECOSYSTEM MANAGEMENT 644-45 (2002).

43 See Tarlock, supra note 7, at 11,277 (using local governments to implement watershed management is complicated by the fact that "[l]ocal governments are locked into the jurisdictional 'box' that state boundary laws draw").

44 See $\mathrm{id}$. at 11,273 (explaining the federal entry into environmental protection historically was justified in part by the experience that "local governments were slow to deal with many environmental problems and, when they did exercise their powers to define and prevent common law nuisances, the result was often to shift pollution to other areas").
} 
the Safe Drinking Water Act. ${ }^{45}$ It is not surprising, therefore, that soil and water conservation districts, which in many states are elected and have political boundaries corresponding to county borders, have generally failed to live up to their promise of comprehensively managing soil and water quality issues. ${ }^{46}$ The emerging generation of "place-based" resource management proposals, while stressing local autonomy, should strive to avoid repeating that history. ${ }^{47}$

Hence, on the one hand there is good reason to believe that the federal government should not attempt to initiate a sweeping federal regulatory scheme for national watershed management. On the other hand, watershedbased management cannot effectively rely exclusively on the initiative and authority of local governance. States, therefore, will have to carry the primary burden of designing and empowering the institutional structure for watershed management. Nevertheless, several of our design parameters also suggest that states should design their internal political frameworks around a hierarchy of physical watershed units and should consider ways to achieve interstate coordination of their respective watershed management efforts. One advantage of initiating watershed management at the state level is to accommodate watershed policy diversity across states and within states. By sharing the same basic governance framework, states can more freely exchange data and experience, and thus work in a more coordinated and efficient pattern to solve both intrastate and interstate watershed problems.

Historical experience also indicates that state-based institutions can be effective in managing hydrologic processes on a watershed scale. For example, drainage districts authorized under model legislation by all Midwestern and several other states in the late nineteenth century were all

45 Public Health Service Act, 42 U.S.C. $\$ \$ 300 f-300 j-26$ (2000). See Faqir S. Bagi, Small Rural Communities' Quest for Safe Drinking Water, 17 RuRAL AM. 40, 40-46 (2002) (explaining that smaller communities have higher per unit costs in complying with the Safe Drinking Water Act). Even at the federal level, there has been a reduction in the already inadequate system of hydrologic gaging stations due to lack of funding. See ADVISORY COMMITTEE ON WATER INFORMATION, REPORT OF THE STREAMGAGING TASK FORCE TO THE ADVISORY COMMITTEE ON WATER INFORMATION OF THE U.S. GEOLOGICAL SURVEY 17 (2002) (recommending additional funding for hydrologic gauging stations to meet national streamgaging goals).

46 Early in the development of environmental regulatory law, some commentators had expressed hope that the county-based soil conservation districts could become the keystone of nonpoint water pollution control. See Dean T. Massey, Land Use Regulatory Power of Conservation Districts in the Midwestern States for Controlling Nonpoint Source Pollutants, 33 DRAKE L. REV. 35, 37 (1983-84) (arguing that soil conservation districts became less effective as their ability to make and enforce regulations decreased). Hampered by their political boundaries, a lack of political will, and a lack of institutional support from the states, this promise was never fulfilled in any meaningful way. See John Davidson, Protecting the Still Functioning Ecosystem: The Case of the Prairie Pothole Wetlands, 9 WASH. U. J.L. \& PoL'Y 123, 144-46 (2002) (arguing soil conservation districts were not effective because they were not organized along watershed lines and lacked police power).

47 We do not mean to discount entirely the possibility that soil and water conservation districts in some states could be "morphed" into the kind of local watershed-based political structure we describe infra. Our point is that it would be difficult and unwise simply to graft the authorities and responsibilities we envision as necessary to carry out watershed management on to the existing structure of soil and water conservation districts. 
too successful in accomplishing the goal of large-scale drainage of wetlands for agricultural development by applying the governmental powers of taxation and eminent domain. ${ }^{48}$ With different purposes in mind, of course, we concur in the following National Research Council's finding:

Organizations for watershed management are most likely to be effective if their structure matches the scale of the problem. Individual local issues related to site planning, for example, should be the purview of local self-organized watershed councils, while larger organizations should deal with broader issues. These larger organizations, however, must include the nested smaller watershed groups within their areas of interest, and must account for downstream interests. ${ }^{49}$

Developing a model framework for a state watershed management law is thus an appropriate exercise.

\section{Key Features of the Model State Watershed Management ACt}

Our model framework for a state watershed management law draws on the experience of several states in the related fields of land-use controls and water quality management, as well as on our jointly coordinated research in Illinois focusing on the locally perceived legitimacy of watershed planning ${ }^{50}$ and on the responsiveness of landowners and landscapes to differing policy environments. ${ }^{51}$ Several states, such as Florida, have adopted multi-tiered approaches to these problems of land-use planning and resource allocation. For example, Florida's land-use planning programs rely on local governments to prepare comprehensive land-use plans, which are then weighed against a set of state land-use standards for consistency with state goals. ${ }^{52}$ Some land-use projects also are evaluated for their regional

48 See John H. Davidson, Commentary: Using Special Water Districts to Control Nonpoint Sources of Water Pollution, 65 CHI.-KENT L. REv. 503, 507-18 (1989) (noting the success of drainage districts in the late nineteenth and early twentieth centuries); Mary R. McCorvie \& Christopher L. Lant, Drainage District Formation and the Loss of Midwestern Wetlands, 1860-1930, 67 AGRIC. HIST. 13, 36 (1993) (arguing that state created drainage districts were effective, but noting that the success of these districts depended largely on technology that made large scale drainage economical).

49 NEW STRATEGIES, supra note 20 , at 3.

50 See generally Ecological Restoration, supra note 26.

51 See Christopher Lant et al., Land Use Dynamics in a Southern Illinois U.S.A. Watershed, 28 EnvTl. MGMT. 325, 325-26 (2001) (studying the links between national policy, landowner decisions on land use, and hydrological impacts); Raja Sengupta et al., Evaluating the Impact of Policy-Induced Land Use Management Practices on Non-Point Source Pollution Using a Spatial Decision Support System, 25 WATER INT'L 437, 443-44 (2000) (presenting a system that models the links between state-wide conservation policies and their impacts on the economy and nonpoint source pollution).

52 See Robert a. Catlin, land Use Planning, Environmental Protection, and Growth MANAGEMENT: THE FloRIDA EXPERIENCE 56-64 (1997) (describing the Local Government Comprehensive Planning Act of 1975 and its implementation through 1990); John M. DeGrove \& Patricia M. Metzger, Growth Management and the Integrated Roles of State, Regional, and Local Governments, in Growth Management: The PlanNIng Challenges of the 1990s 13-15 (Jay M. Stein ed., 1993) (describing the role of local government in Florida's top down growth 
impact-i.e., impact that extends beyond political boundaries. ${ }^{53}$ Therefore Florida uses a blend of different scales of authority (state, regional, and local) and sources of legitimacy (elected and appointed) in a variety of landuse and resource management contexts, and in some cases has designed political units around the resource problem rather than the reverse. Many other states have attempted to develop land-use regimes that integrate state, regional, and local planning. ${ }^{54}$

Washington's Watershed Planning Act, which is based on local geographic areas known as Water Resource Inventory Areas, ${ }^{55}$ and Oregon's Watershed Health Program, which operates in part through Watershed Councils, ${ }^{56}$ provide examples of states entering the watershed management realm with this kind of integrated, hierarchical approach. Similarly, Florida uses a regional approach to manage many of its water quality and allocation issues, through its several Water Quality Management Districts, each of which is defined by regional watershed boundaries. ${ }^{57}$ Overall, however, most states purporting to adopt statewide watershed management approaches omit important water resource authorities from the program, such as wetlands protection, coastal land-use regulation, water quality standards, and even nonpoint source pollution control, and fail to link watershed management with local planning and zoning decisions. ${ }^{58}$

In contrast, the new Québec Water Policy in Canada features an innovative approach to managing provincial water resources that is based on "grassroots participation and the democratization of information." Among the central tenets of this new vision is "water governance reform," which is organized around watershed management and leadership at both local and

management system).

53 See CATLIN, supra note 52, at 53-54 (noting that large projects can have a substantial effect on more than one county "because of [their] character, magnitude, and location"); DeGrove \& Metzger, supra note 52, at 9-12 (noting that the primary role of regional plans is to address impacts that "transcend jurisdictional boundaries").

54 See DeGrove \& Metzger, supra note 52, at 9-12 (describing the role of Regional Planning Commissions in Maine, Georgia, and Vermont).

55 A Review of Statewide Watershed Management Approaches, supra note 19, at 64-65. See generally WASHINGTON STATE DEP'T OF ECOLOGY, WATERShed PLANNING, at http://www.ecy.wa.gov/watershed (last visited Nov. 16, 2003) (explaining the importance of local development of watershed plans under the Watershed Planning Act).

56 See A REVIEW of STATEWIdE WATERShed MANAGEMENT APPROACHES, supra note 19, at 5961 (summarizing Oregon's multiagency approach under the Oregon Plan for Salmon and Watersheds and the Governor's Watershed Enhancement Board). See generally OREGON DEP'T

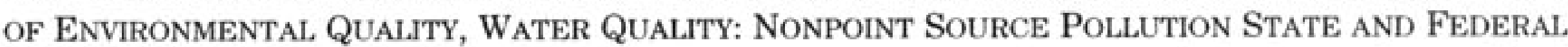
INITIATIVES AND AGENCIES, at http://www.deq.state.or.us/wq/nonpoint/other.htm (last visited Nov. 16, 2003) (describing the Oregon Watershed Health Program and the role of watershed councils).

57 Fl.A. STAT. ch. 373 (2003). See generally Mary Jane Angelo et al., Exalting the Corporate Form Over Environmental Protection: The Corporate Shell Game and the Enforcement of Water Management Law in Florida, 17 J. LAND USE \& ENvTL. L. 89, 94-103 (2001) (providing an overview of Florida's regional approach).

58 See A REview of Statewide Watershed Management Approaches, supra note 19, at 4950 (recommending to states ways to improve their approaches to watershed management).

59 Bernard Landry, A Word from the Premier, in Environment QuÉBEc, QuÉbec Water POLICY: WATER. OUR LIFE. OUR Future (2002). 
regional levels under the provincial guidance of the government of Québec. The revision of water governance now under way includes establishing mechanisms for implementing the "user-pays" and "polluter-pays" principles that are supported by a variety of economic mechanisms. The revision also calls for the implementation of watershed-based management built on the principle of sustainable development. A Minister of State has been appointed to oversee the vertical integration of water management that, among numerous other charges, calls for accountability of all concerned parties. ${ }^{60}$

At the national level, Brazil ${ }^{61}$ and Australia ${ }^{62}$ also have engaged in institution-building processes to improve land management practices on a watershed basis. New Zealand went further by enacting the Resource Management Act of 1991 and the country has experienced considerable success by organizing environmental administration around watersheds as districts. $^{63}$

Borrowing, combining, and enhancing a number of features from these examples, we have designed a multi-tiered approach that can distribute funding, authority, and other resources in a way that addresses many of the design parameters discussed above. In particular, our approach aims to establish legitimacy for watershed management at the local level while not sacrificing broader state and regional concerns. The framework relies on creating and coordinating institutions at three levels of government, including: 1) the state watershed management agency, 2) appointed regional watershed coordination districts, and 3) elected local watershed management councils. Each level of government must prepare a watershed management plan for its respective scale of focus. In the case of the regional and local entities, the plan must be consistent with the plan that is vertically above it in the tiered system. The state agency would continue to direct policy for matters of statewide concern, including developing a state watershed management plan, but would delegate most watershed management policy development, implementation, and enforcement authority to the regional districts. The regional districts would develop regional plans to implement the state plan, and would be the locus of most planning and policy expertise. They would have staffs including engineers, biologists, economists, hydrologic modelers, information specialists, conservation experts, and lawyers. Yet the regional districts would still rely

60 Similarly, the proposed Model Act to Conserve Ontario Waters would support integrated watershed management through hydrologically based Water Planning Boards. CANADIAN ENVTL. LAW ASS'N, AN ACT TO CONSERVE ONTARIO WATERS 15-16 (2001).

61 See Monica Porto et al., A Participatory Approach to Watershed Management: The Brazilian System, in Human Dimensions of WATERShed MANAGEMENT, AMERICAN WATER Resources Association, Monograph Series No. 20, supra note 9, at 675-83 (examining the development of Brazil's water resources management system).

62 See S. Ewing, Landcare and Community-Led Watershed Management in Victoria, Australia, in Human Dimensions of WATERShed MANAgEMEnT, AMERICAN Water Resources Association, Monograph Series No. 20, at 663-74 (Christopher L. Lant ed., 1999) (reviewing Australia's Landcare Program and the movement toward the creation of watershed based management programs).

63 Eric Pyle et al., Establishing Watershed Management in Law: New Zealand's Experience, 37 J. AM. WATER Resources Ass'N 783, 783-93 (2001). 
in large part on the elected local councils for final policy development, implementation, and enforcement.

To fulfill this role, the local councils must be more than mere "special districts" (lest they wither the way many other special district initiatives have), and more than conventional local governments. The local councils would be organized around watershed-based boundaries and held accountable to state and regional interests through the requirement that their local plans be consistent with the regional (and thus state) plans. Perhaps even more importantly, local councils would coordinate the review of all land-use decisions by other existing state and local authorities, such as state highway agencies and municipal and county zoning authorities, for consistency with the state, regional, and local watershed management plans. This would extend the policy reach of watershed planning beyond the direct management of water resources.

This framework allows our institutional structure to match the physical realities of watersheds in both the vertical and horizontal dimensions. The vertical integration of local, regional, and state planning and regulatory authority matches the nested hierarchies of watershed scales. The ability at each level of this structure to examine the horizontal impacts the decisions of other governmental authorities have on watershed resources matches the dynamics of watershed processes at each physical scale. Accounting for each of these dimensions in the institutional design is necessary for successful implementation of watershed management, but none of these features is sufficient alone.

\section{THE PROPOSED INSTITUTIONAL FRAMEWORK}

Using the three-tiered institutional structure described above, we propose distributing watershed management responsibility and authority as follows:

\section{A. State Watershed Management Agency}

Every state has a state agency responsible for developing law and policy for the protection of water quality. Many states also have a state agency or set of institutions responsible for water allocation. Under our proposal, the two functions would be consolidated into a single state agency or division referred to as the State Watershed Management Agency. This agency would continue to serve as the original authority for statewide water quality and quantity regulation, and would implement federal laws, such as the Clean Water Act's water quality standards and impaired water lists. Under the state watershed law, however, the agency would also be required to:

1) Prepare a State Watershed Management Plan specifying the goals for watershed management in the state. ${ }^{64}$

64 This tracks Florida's land-use system, in which a state land-use plan is intended to guide local planning implementation. See supra notes 52-53 and accompanying text for a discussion 
2) Delegate responsibility to Regional Watershed Coordination Agencies (RWCA) for implementing programs that affect "matters primarily of regional or local watershed significance." Matters of primarily regional or local watershed significance would be defined in the statute to include: a) rules and decisions specified in the statute, and b) any other types of rules or decisions that the State Watershed Management Agency prescribes by rule. ${ }^{65}$

3) Include in its deliberations on statewide decisions and rules within its authority any information and comments supplied by RWCAs. ${ }^{66}$

4) Review the Regional Watershed Management Plans for compliance with the State Watershed Management Plan and provide corrective elements in case a plan is deficient. ${ }^{67}$

5) Review and comment on the actions of all other state and regional agencies that are deemed to have "substantial watershed effects." Substantial watershed effects are any effects the State Watershed Management Agency concludes could substantially interfere with the State Watershed Management Plan, any Regional Watershed Management Plan, or any Local Watershed Management Plan. ${ }^{68}$

\section{B. Regional Watershed Coordination Agencies}

The Regional Watershed Coordination Agencies (RWCAs) will be organized based to the extent practicable on the 222 subregional hydrological units the United States Geological Survey (USGS) has defined for the nation, ${ }^{69}$ as constrained by state boundaries. RWCAs will be appointed boards with significant staff and budgets. Because they will take over many functions previously managed by the state agency, their budgets will be state appropriated. Each RWCA will do the following:

of Florida as an example of a state with a plan that promulgates substantive standards and criteria under which regional and local plans can be evaluated.

65 This is one of several provisions designed to match the scale of the problem with the scale of the political institution.

66 Matching problem scales to institutional scales does not mean that the different layers of political institutions operate independently. This provision, for example, is one of many in which information gathered at one level is channeled up or down the vertical hierarchy of institutions to inform decision making at another level.

67 The threat of plan development by the higher institutional authority is designed to motivate meaningful plan development at the lower level.

68 This fulfills the horizontal dimension function of the institutional structure, allowing the watershed management agencies to influence decisions made by other agencies operating at the same scale where an effect at that scale can be demonstrated.

69 USGS, HYDROLOGIC UNIT MAPS (explaining USGS hydrological unit maps of the United States at various watershed levels), http://water.usgs.gov/GIS/huc.html (last updated Oct. 29, 2003). But see James M. Omernik, The Misuse of Hydrologic Unit Maps for Extrapolation, Reporting, and Ecosystem Management, 39 J. AM. WATER RESOURCES Ass'N 563 (2003) (explaining that in some cases the USGS scaled maps, because they seek to delineate watersheds of roughly the same size at each scale level, do not reflect true topographic watershed boundaries; in such a case, the state would probably want to consider reconfiguring the boundaries of the regional authorities to avoid serious departures from the physical watershed). 
1) Establish the Local Watershed Management Council boundaries as it deems appropriate, but to the maximum extent practicable according to the 2150 USGS watershed cataloging units. ${ }^{70}$

2) Establish a Regional Watershed Management Plan (RWMP) demonstrating how it will satisfy compliance with a) all federal and state laws governing water quality and quantity, and b) the State Watershed Management Plan. ${ }^{71}$

3) Decide all matters of primarily regional watershed significance that are prescribed in the statute or by the State Watershed Management Agency. ${ }^{72}$

4) Review Local Watershed Management Plans and develop one for any Local Watershed Management Council that fails to meet the State Watershed Management Plan and Regional Watershed Management Plan criteria. $^{73}$

5) Define Special Watershed Areas. ${ }^{74}$

6) Define the criteria for land-use and water project developments to be classified as a Development of Regional Watershed Impact. ${ }^{75}$

7) Review local government land-use and water project decisions that are either a) in Special Watershed Areas, or b) for a Development of Regional Watershed Impact, and impose the conditions it deems necessary to ensure compliance with the Regional Watershed Management Plan. ${ }^{76}$

8) Hear appeals from local governments and citizens of Local Watershed Management Council decisions on local government land-use and water project development matters, including whether a project is in a Special Watershed Area or is a Development of Regional Watershed Impact. ${ }^{77}$

9) Provide the scientific, economic, and social-data gathering and analysis capacity for implementation of the Regional Watershed

70 As an example of this hierarchical assembly of boundaries, Appendix 1 illustrates how the USGS boundaries would configure the regional and local political boundaries used in our proposal for the state of Illinois.

71 Critical regulatory decisions would therefore be reflected in the regional plans.

72 The regional agencies would also be where most regulatory decisions are made.

73 This duplicates the state-regional plan development relationship at the regional-local levels.

74 This provision is designed to withdraw from primarily local decision-making authority any area that, while not regional in geographic scope, presents important regional concerns. It is patterned after Florida's land-use program for "areas of critical state concern," through which the state's land-use agency can require local zoning authorities to submit decisions affecting such areas for state review. See CATLIN, supra note 52, at 53-54 (listing characteristics of "areas of critical state concern" designations and mentioning potential problems with vesting ultimate responsibility for regional impact and land-use decisions in local government).

75 This provision is patterned after Florida's land-use program for "developments of regional impact." See supra note 53 and accompanying text. This provision recognizes that some development projects, while located entirely within the boundaries of a single local watershed district, have transboundary effects at that scale.

76 Special Watershed Areas and Developments of Regional Watershed Impact thus are withdrawn from the primary local authority due to their regional significance.

77 This establishes additional regional oversight of the local councils through an appellate function. 
Management Plan and the various Local Watershed Management Plans within its jurisdiction. ${ }^{78}$

10) Notify the State Watershed Management Agency of any state agency or regional agency action it believes may substantially interfere with the Regional Watershed Management Plan. ${ }^{79}$

11) Serve as the primary points of contact for the state with federal agencies, such as the Army Corps of Engineers, with respect to past, present, and future civil and environmental development projects that may have a substantive impact on the achievement of the Regional Watershed Management Plan. ${ }^{80}$

\section{Local Watershed Management Councils}

The Local Watershed Management Councils would be generally elected local governmental bodies. ${ }^{81}$ They would have the following authorities and responsibilities:

1) Prepare a Local Watershed Management Plan demonstrating how the Council will achieve compliance with the Regional Watershed Management Plan. ${ }^{82}$

2) Review all local government land-use and water project development applications. Local governments, defined to include municipalities, counties, and other special entities such as irrigation districts and soil conservation districts with jurisdiction extending to all or part of the Council's area, would be required to provide advance notice of their proposed actions and decisions to the Council. The Council then would either a) find the matter has no significant local watershed, regional watershed, or Special Watershed Area impacts and take no action, b) for those matters the Council deems to have the potential for significant local

78 As the middleman for most decision making in our proposal, the regional agencies would be the locus of most of the watershed management staffing of the state and would provide the technical and policy development support for local councils.

79 Because the regional agencies will be primarily responsible for putting technical expertise into the field and monitoring watershed and land-use dynamics, they serve as the "eyes" of the state agency.

80 This places the federal-state liaison function for development projects at the relevant physical scale.

81 One of the principal findings of our work on watershed management institutions is that local communities place more trust in locally elected institutions than in administrative bodies. See Ecological Restoration, supra note 26, at 165 (noting that residents of the Cache River watershed in Illinois saw value in a watershed management institution "only if it was based on local input"). The trick is to ensure that the local elected officials have the resources, authority, and political will to make and implement meaningful policy choices-the objective of the tiered institutional framework we are proposing. See MARCO JANSSEN ET AL., ROBUSTNESS OF SOCIALEcological Systems to Spatial and Temporal Disturbance Regimes, Paper No. W03-21, WORKSHOP In POLITICAL THEORY AND POLICY ANALYSIS, InDIANA UNIVERSITY 29 (2003) ("The delicate problem in designing multi-level systems is how to empower local resource users and public infrastructure providers to have considerable autonomy in designing rules that are well matched to local circumstances but fit ... into a larger system.").

82 The regional plan thus provides an external constraint on local officials who may find it politically expedient to blame difficult local decisions on the regional authority. 
watershed impacts, provide the conditions the Council deems necessary to ensure compliance with the Local Watershed Management Plan to local governments, or c) for those matters the Council deems to be located in Special Watershed Areas or to constitute a Development of Regional Watershed Impact, refer the matter to the Regional Watershed Management District. $^{83}$

3) To acquire (including by eminent domain) and manage lands it deems important to local watershed management and fulfillment of the Local Watershed Management Plan. ${ }^{84}$

4) To finance its operations through property taxes, recreational-user fees, water-utility fees, and development-permit fees, including fees levied as a surcharge, and through bonds. ${ }^{85}$

5) To notify the State Watershed Management Agency of any state or regional agency action it believes may substantially interfere with the Local Watershed Management Plan. ${ }^{86}$

6) To develop processes for citizen volunteers to participate in the development of Local Watershed Management Plans through planning forums undertaken at the sub-basin level as delineated by the Council. ${ }^{87}$

\section{CONCLUSION}

The challenges of water resource management in the United States traditionally have been water resource development, structural flood control, and centralized treatment of drinking water and wastewater. Increasingly, however, the focus is shifting to the management of land uses to prevent polluted runoff and groundwater contamination, the restoration of the physical integrity of rivers to reverse declines in aquatic ecosystems, and the promotion and protection of environmental services those ecosystems could potentially produce. This shift in goals also requires a shift in institutional structure from a system of congressional appropriations for cost-sharing of largely federalized civil and environmental engineering

83 Most development projects do not have state or regional implications, so we anticipate that most of the horizontal function of watershed management-the evaluation of nonwater land use and other engineering projects on watershed conditions-would take place at the local council level. The local councils could rely on the regional agency for technical and modeling support in carrying out this function.

84 We also anticipate that many of the local councils would assume the role of a significant public land trust, with watershed quality maintenance as its primary goal.

85 Although the local councils can lean on the regional agency for technical support, councils with authority over large or urban areas may desire substantial capacities on their own. Significant expenditures may also be involved for local councils that aggressively take on the land trust role. Thus, a secure funding base is essential at the local level.

86 Local authorities may be reluctant to take on regional and state land-use and development agencies, and thus could refer a matter up the watershed management chain of command.

87 Our work and that of others suggests that the ability of citizens to participate in watershed-based planning through voluntary forums in local contexts contributes to the final product's legitimacy. But see Kenney, supra note 9, at 501 (cautioning that watershed initiatives, because they are generally informal, may contribute to the avoidance of divisive issues). 
projects to a system of watershed-based, state-facilitated, locally led planning and management of economic incentives. In most states, unfortunately, these institutions do not exist in a form that has the political power and local legitimacy necessary to accomplish these goals.

In this Article we have proposed a structure for such institutions that is amenable to wide application among the fifty states and is guided by the political and other considerations required to meet twenty-first century challenges in water resources management. We acknowledge that in many states the proposal would add to the "layers" of governmental structure and for that reason will not be politically popular. These layers, however, are designed to match politics with the physical reality of one of our nation's most important resources-water. We believe the layers are worth considering. Every jurisdiction, state or national, that has seriously undertaken watershed management implementation has arrived at the same conclusion.

We welcome comments on the proposal at this stage, as we plan to undertake the task of putting meat on its bones by drafting its specific provisions.

\section{APPENDIX 1}

Geographical comparison of 38 U.S. Army Corps of Engineers Districts, 222 U.S.G.S. water resource regions, and, for the state of Illinois, its 52 USGS watersheds.

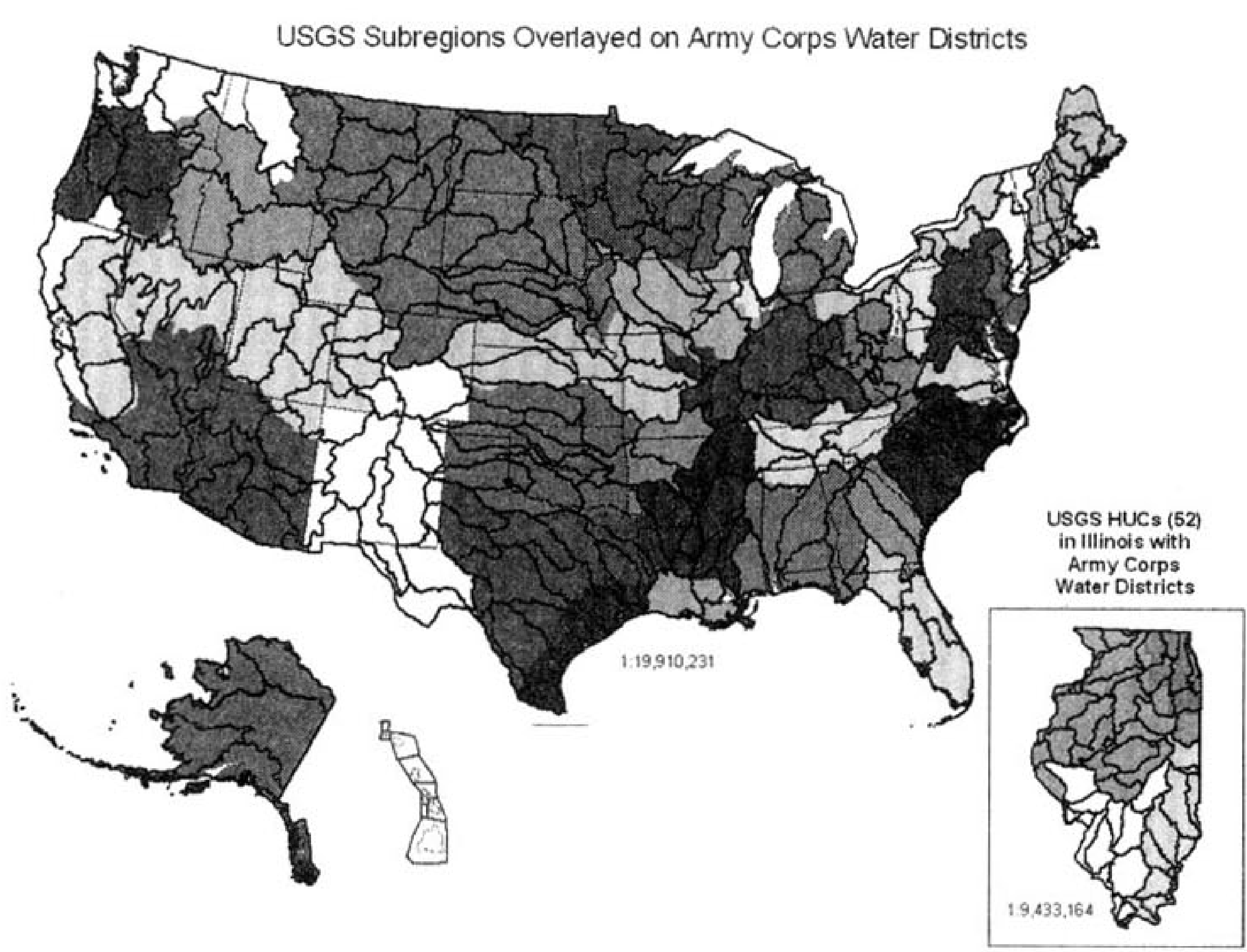

